though people did not expect from psychology progress in knowledge, but some other kind of satisfaction; every unsolved problem, every acknowledged uncertainty, is turned into a ground of complaint against it". Such an opinion from one whose chief activities have been concerned with the subjective world reflects poorly on those who condemn an objective approach to psychology because the fruits it has yielded are as yet neither rich enough nor abundant enough for their taste.

1 "The Advancement of Science, 1934". British Association. ibid.

3 Nature, 134, 340, Sept. 8, 1934.

" "New Introductory Lecture on Psycho-Analysis".

\title{
Obituary
}

\section{Prof. KaRL voN LINDE}

$\mathrm{P}$ ROF. KARL VON LINDE, who died on November 16 at the age of ninety-two years, was for more than half a century prominent in the refrigeration industry. He was born on June 11, 1842, in Berndorf, and studied at the Erdgenoss Polytechnic, Zurich, where Zeuner taught the theory of machines. In 1868, at twenty-six years of age, linde became extraordinary professor of mechanical science at the Munich technical college which had just been founded. In 1870 he produced his main paper on "The Extraction of Heat at Low Temperatures through Mechanical Means", in which he proved that none of the refrigerating machines hitherto built had given more than one-fifth of the theoretical capacity. IIn 1874 he introduced the ammonia refrigerating machine, the first patents on the ammonia compression machine having been taken out by him in 1870. Linde's machine, besides being thermodynamically efficient, was characterised by the excellence of its mechanical design.

In 1891, the Linde British Refrigeration Co. supplied meat freezing plants to New Zealand and Australia, thus participating in laying the foundation of what is now a huge frozen meat industry.

In Germany Linde's patents were exploited by the Lindes Eismaschinen AG. founded at Wiesbaden in 1879. In 1891 he retired from the chairmanship of the company in order to resume his work at the Technical High School, Munich.

Another notable invention of linde was his air liquefying and oxygen producing apparatus. The apparatus is described in British Specification No. 12528 of 1895 , and it comprises an air compressor communicating with a reversed flow heat interchanger having two tubes of different diameters and about $300 \mathrm{ft}$. long; one tube is inserted in the other so as to leave an annular space and both are coiled helically, the coils being insulated by raw sheep's wool.

The compressed gas, after expansion at the regulating valve, flows back in the annular space to the compressor, whilst after operating for some time a portion is liquefied. In the same patent, Linde described his apparatus for obtaining oxygen from liquid air by fractional evaporation. The products were substantially pure oxygen and nitrogen mixed with a rather large quantity of oxygen. The purer the oxygen the less was the yield. In a subsequent improvement Linde treated the liquid air in a rectifying column and completed the process of separating the oxygen and nitrogen by a fractional evaporation.
After devising the method for the production of liquid air, Linde found an application for the liquid rich in oxygen obtained by the partial evaporation of liquefied air. He showed that when mixed with wood charcoal or other combustible material a powerful explosive was obtained.

Linde's interest in low temperature technology continued throughout his life, and at the age of eighty-three he applied refrigeration to the problem of separating from coke oven gas the constituents hydrogen, methane, carbon monoxide and nitrogen.

Linde was ennobled for his services to science.

E. G.

\section{Mrs. H. S. WILTIAMSON}

WE regret to record the death on December 4 of Mrs. H. S. Williamson. She was born in 1884, educated at the Royal Holloway College and published her early papers in her maiden name of Chambers from 1908 onwards. She held posts at the Universities of Sheffield and Belfast, and at the Royal Holloway College. In November 1914, she married Ernest Lee, whose work on leaf-fall indicated his great promise ; he was killed in action in 1915. In the autumn of that year, she trained for bacteriological work and replaced in the Seamen's Hospital at Greenwich an official proceeding on active service.

In 1920, while employed at the Imperial College of Science and Technology, she married Mr. J. W. Williamson, secretary to the British Scientific Instrument Research Association. In 1926 she accepted the post of research assistant to the professor of botany at Birkbeck College, and was joint author of a series of papers on the fungi.

Mrs. Williamson possessed an unusually fine technique, was a careful and critical observer and, as many can testify, an excellent friend and colleague.

H. C. I. G.-V.

WE regret to announce the following deaths :

Mr. J. A. Brodie, formerly city engineer of Liverpool, president of the Institution of Civil Engineers in 1921 , a pioneer in modern methods of road construction, on November 16, aged seventy-six years.

Prof. S. H. Gaiger, professor of veterinary pathology in the University of Liverpool since 1926, and president of the Royal College of Veterinary Surgeons, on December 14, aged fifty years.

Prof. S. P. Mulliken, professor of organic chemistry in the Massachusetts Institute of Technology, on October 24, aged sixty-nine years. 